Global Conferences Series:

Social Sciences, Education and Humanities (GCSSSEH), Volume 2, 2019

The $2^{\text {nd }}$ International Conference on Sustainable Development \& Multi-Ethnic Society

DOI: https://doi.org/10.32698/GCS.01102

\title{
Career Planning: Issues and Challenges for Special Education Students with Learning Disabilities
}

\author{
Mohd Khaidir Othman ${ }^{1}$, Mohd Mahzan Awang ${ }^{2}$, Abdul Razaq Ahmad ${ }^{3}$ \& Anuar \\ Ahmad $^{4}$ \\ ${ }^{1234}$ Faculty of Education UKM, MALAYSIA \\ E-mail: khaidirothman82@gmail.com
}

\begin{abstract}
Malaysia is estimated to have over 32 million people today and 2 million of them are disabled. The biggest challenge for the disabled today is the competition for job opportunities once they finish school. Some of these group are fortunate to be able to pursue higher education such as colleges and universities and some are home-based parents. In-short, the social and career development of the disabled depend on the people closest to them such as parents and teachers. Parents and teachers have played an important role in the early development of the sociology of special education students to look for opportunities and shape their direction after school. They have to compete with normal people to attract employers to fill the position they offered. This concept paper is designed to identify issues and challenges faced by special education students with disabilities or learning problem categories in preparation before entering the job market in the face of this increasingly challenging era. The issues and challenges to be addressed are the confidence of the parents themselves, the mastery of skills by special education or disabled students, the opportunities offered, the confidence of potential employers, and competition with normal people. The survey will be conducted on the target geologists such as parents, special education teachers and prospective employers using quantitative methods. The study will be conducted in 22 schools at Masjid Tanah, Melaka integrated special education programmed respectively. Hopefully, the findings of this study will open up positive views from parents, special education teachers and prospective employers on the employment needs of the disabled in the face of today's socioeconomic competition.
\end{abstract}

Keywords: Special education students/ disability people (OKU), career opportunities, prospective employers.

\section{Introduction}

Special education students are also known as special needs students. These students include those with dementia, dyslexia, hyperactive deficits, emotional and behavioral problems, mental retardation, Down syndrome, autism, cerebral palsy, and learning disabilities. In this paper, the focus is on students with learning problems. Students with learning problems are students who have difficulty in language, speech, reading, writing, reasoning and counting. 
It is a common knowledge that special education students rely heavily on individuals around them, such as parents, friends, teachers and the community to meet the challenges of life from school to work. These students need constant support so that they can enjoy a more comfortable life in terms of social, educational, medical, social and employment opportunities. Currently, the choice of education is a major focus of Malaysia's educational development plan, (2013). According to a previous study conducted by Daviso et al. (2011), choosing the right educational setting can open up the opportunity for the students to pursue higher education. While Condon and Callahan (2008) argue that it determines the success of a student's career.

Likewise with special education students, various areas of expertise are offered to them. The question is, do special education students who have this learning problem can master the level of skills required by the existing job market compared to the other normal students while attracting future employers?. This clearly shows that these students deserve the attention of the various parties such as parents, teachers, and future employers and the support of the community itself to provide better opportunities for this group.

\section{Literature review}

According to the disabled people Act 2008, people with disabilities in Malaysia are defined as persons with long-term physical, mental, intellectual or emotional disabilities who, when interacting with various obstacles, can restrict their full and effective participation in society.

According to the Tenth Malaysia Plan (2011-2015), an estimated 13.2 million new job opportunities will be created in 2015 , while the unemployment rate is 3.1 percent in 2015. However, the question is how far this comprehensive information goes our students in general and students with disabilities especially before they leave school?

According to Ilona (2010) in her study, she found that there are three main challenges in integrating disabled workers within the organization, how to attract disabled people to work, how to provide a conducive workplace environment and how the interpersonal relationship between employer and employee needs to happen. According to Ta and Leng (2013), people with disabilities in the labor market have to face two major challenges- discrimination and exploitation.

Ju, Zhang and Pacha (2011) in their study, found that lack of employability skills was a major factor that prevented the disabled from gaining a place in the open job market. "Employability" refers to the general competencies required to perform certain types and levels of work such as communication skill, problem solving skills, teamwork and interpersonal skills.

\section{Statement of Problem}

The purpose of work experience is to help students with special education disabilities be prepared to succeed in school, work and live independently. Many people with disabilities have problems finding a productive job and earning a living after graduation. The number of people with disabilities who are able to find jobs in the public and private sectors is less encouraging. The total number of 1,500 people with disabilities in the public sector is far from the target of 1.4 million civil servants nationwide (Disability Policy and Action Plan,2007). Why does this happen, can the disabled worker not be able to produce the same from productivity as the normal worker? What are the challenges that these disabled people face from the very beginning and limit their opportunities to compete for jobs?

Zainuddin (2004) argues that society generally plays a role in improving the careers of the disabled so that they can live independently. These roles are based on the position and function of society such as changing people's negative perception of the disabled. According to Khalil (1988), under normal circumstances an employer is more willing and willing to employ a normal worker who can perform more than one task regardless of the obstacles and constraints compared to the disabled. Realistically or not, there are actually many issues and challenges that special education students have to face in learning to get to the real world in relation to the people around them.

\section{Issues and challenges}

The issues and challenges presented in this concept paper are the conditions that underpin the development or career opportunities of students with disabilities who study after graduation.

\subsection{Parents of Love Binders}

Parents are the closest people who know the needs of children with disabilities because they are the ones who give birth and raise special children and have spent a lot of time together. It is for this reason that some parents cannot stay away from their children, let alone get them out of work without their eyes watching. Indirectly, these factors have limited the opportunity for these special children to live independently by finding their own jobs. The question is, how often do parents want to "defend" them under their 
care? What will happen to these children when their parents are gone? This is something that parents need to know from the beginning.

Parents who care for children with disabilities should design and prepare their special children with work skills, get used to real life situations and not always be in a comfortable zone so that they can be more prepared for the real life situations.

\subsection{Teacher as a Bridge To Knowledge}

In general, teachers have a great responsibility in realizing the aspiration of the nations

education to produce people who are skilled, capable, believing, self-reliant and potential leaders of the future. This focus is not only for the normal students but also for these students with disabilities. This role will be played by these special education teachers themselves. Same as parents of special children, special education teacher should not placed students with disabilities in this learning zone in the comfort of their school again using their reasons for disabilities, these students cannot do their homework or hard skills. This has indirectly causes teachers to make their own decisions without giving these students a chance to prove it first.

At the school level, special education teachers need to incorporate of the curriculum such as entrepreneurship and career transitions to these students as well as teaching specific subjects. This is important as it opens the minds of students about career opportunities after graduation. According to Shulman (1998), teachers should plan and implement effective teaching practices through practical practice and the integration of knowledge to transform negative into positive behaviors. This clearly shows that teachers play a vital role in designing career opportunities for these special needs students.

\subsection{The Acceptance of Future Employers and the Public}

According to the Peninsular Malaysia Department of Labor (JTKSM), the main problem faced by people with disabilities in obtaining employment is due to the attitude of employers themselves who are less interested in hiring people with disabilities. Employers may consider the involvement of these groups in the organization to have their impact such as insufficiency, limited self-management, necessary infrastructure provision and job security.

A study conducted by Haward (2000), 50\% to $70 \%$ of people with disabilities is unemployed and some of them receive a minimum income. Similarly, according to a study conducted by Rahimah Mohd Nor (2010) who found that people with disabilities find it difficult to get a job due to the attitude of the employer to underestimate the ability of the disabled. This problem is related to the attitude of prospective employers and the people who are negatively perceived by the disabled as having no ability to work and to be competitive while these groups also have specific skills learned at school or tertiary institutions in preparation for employment. This clearly shows that the disabled need the support of their employers and the community to find a place in the workplace.

\section{Conclusion}

Special education students with learning disabilities and people with disabilities really need the support of all of us to live and improve them. In order to realize this, all parties, especially the individuals and the community must work together to achieve this goal. If we do not go to great lengths to help these people, they will surely remain isolated in the era of modern nationhood and the ever-expanding world. Changes in perception need to be made remove the stigma that this group is unable to provide the best. Is like Malay proverb say, " kalau tidak dipecahkan ruyungnya, manakan nak dapat sagunya". As long as the opportunity is not given, they have no chance to show their potential in the job market and will continue to be sidelined in the spin of the society's sociology.

\section{References}

[1] Condon, E, and Callahan, M. "Individualized Career Planning for students with significant support needs utilizing the discovery and vocational profile process, cross-agency collaborative funding and social security sork incentives." Journal of Vocational Rehabilitation 28, (2008): 85-96.

[2] Daviso, A, W., Denney, S. C., Baer, R. B, and Flexer, R. "Postschool Goals and Transition Services for Students with Learning Disabilities." American Secondary Education 39,no.2(2011): 77-93

[3] Hazlin Falina Rosli, Safura Ahmad Sabri, Norazla Abdul Wahab, \& Nurzakira Afnee Zakaria" kesedaran golongan majikan terhadap orang kurang upaya (oku) di Malaysia: melalui perspektif media" Proceeding of the 2 nd International Conferenc on Management and Muamalah 2015 (2nd ICoMM) 16th- 17th November 2015, e-ISBN: 978-967-0850-25-2

[4] Jabatan Kebajikan Masyarakat Malaysia. (2014). Profil Statistik Jabatan Kebajikan Masyarakat Kuala Lumpur: 
Kementerian Pembangunan Wanita, Keluarga dan Masyarakat.

[5] Noor Aini Ahmad dan Norhafizah Abu Hanifah" tahap pengetahuan guru pendidikan khas apabila mengurus tingkah laku murid bermasalah pembelajaran" AsiaPacific Journal of Educators and Education, Vol. 30, 73-88, 2015

[6] Pelan Pembangunan Pendidikan Malaysia. 2013-2015. Kementerian Pendidikan Malaysia, 2013

[7] R. Ibrahim, M. H. M. Yasin and N. Abdullah" Pemilihan Bidang Pendidikan bagi Murid Berkeperluan Khas Bermasalah Pembelajaran" Journal of Advanced Research in Social and Behavioural Sciences ISSN (online): 2462-1951 | Vol.3, No. 2. Pages 152-161, 2016.

[8] Shulman, L. S. (1998). Theory practice and education of professionals. The Elementary School Journal, 98(5), 511-526.

[9] Siti Suhaila binti Samiana, Khadijah binti Md Ali \&Yahya bin Buntat" Persepsi Majikan Terhadap Pekerja Orang Kurang Upaya (OKU) dalam Organisasi di Negeri Johor" 2nd International Seminar on Quality and Affordable Education (ISQAE 2013) 